\title{
SISTEM PENDUKUNG KEPUTUSAN PEMBERIAN KREDIT PADA KOPERASI SERBA USAHA BERKAH TIRAM JAYA MENGGUNAKAN METODE ANALYTIC HIERARCHY PROCESS (AHP)
}

\author{
Heri Nurdiyanto ${ }^{1}$, Sulung Yoga Minarto ${ }^{2}$ \\ Program Studi Teknik Informatika, STMIK Dharma Wacana \\ Jl.Kenanga No.03 Mulyojati 16C Metro Barat Kota Metro 34125 \\ Email : $\underline{\text { herinurdiyanto@gmail.com }}{ }^{1}, \underline{\text { Sulungyogaminarto@gmail.com }}^{2}$
}

\begin{abstract}
Sistem Pendukung Keputusan (SPK) adalah sistem yang dapat membantu seseorang dalam mengambil keputusan yang akurat dan tepat sasaran. Banyak permasalahan yang dapat diselesaikan dengan menggunakan SPK, salah satunya adalah penentuan kelayakan nasabah penerima kredit. Ada beberapa metode yang dapat digunakan dalam membangun suatu SPK diantaranya analytical hierarchy process (AHP). AHP merupakan metode yang paling banyak digunakan dalam memecahkan permasalahan yang bersifat multikriteria, seperti dalam SPK penentuan kelayakan nasabah penerima kredit. Penelitian ini menggunakan metode AHP dalam menentukan kelayakan nasabah penerima kredit pada Koperasi Serba Usaha Berkah Tiram Jaya. Dalam penentuan kelayakan nasabah penerima kredit, ada beberapa kriteria yang menjadi dasar pengambilan keputusan antara lain usia, perkerjaan, status keanggotaan, pendidikan, produktivitas usaha, kolektabilitas, besar simpanan awal, jangka waktu angsuran, besar bunga, penghasilan perbulan, pengeluaran perbulan, tanggungan keluarga, jaminan, status kredet, dan kredibilitas. Adapun hasil akhir dalam penelitian ini adalah hasil prioritas global kriteria nasabah, yang diurutkan dari yang tertinggi hingga terendah, sehingga pihak koperasi dapat dengan mudah mengambil keputusan dengan melihat hasil tersebut.
\end{abstract}

Keyword : SPK, Kredit, koperasi, ahp

\section{Pendahuluan}

\subsection{Batasan Masalah}

Koperasi simpan pinjam adalah salah satu jenis koperasi yang ada di Indonesia yang mempunyai kegiatan utama adalah menyediakan jasa penyimpana dan pinjaman dana kepada anggota koperasi dengan tujuan memajukan kesejahteraan anggota khususnya pada masyarakat pada umumnya. Koperasi Serba Usaha Berkah Tiram Jaya adalah jenis koperasi simpan pinjam aktif, yang memanfaatkan dana dari anggota yang berupa simpanan kemudian menyalurkan kembali kepada anggota dalam bentuk kredit atau pinjaman. Jenis kredit yang digunakan adalah jenis kredit menurut waktu yang pengembaliannya memerlukan jangka waktu pendek, menengah dan panjang. Didalam jangka waktu tersebut koperasi juga sering menghadapi resiko. Misalnya koperasi tidak menerima pembayaran dimuka ataupun sering terjadinya penunggakan atau keterlambatan dalam pembayaran dikarenakan berbagai alasan nasabah. Oleh karena itu, koperasi menentukan kebijakan dalam pemberian kredit antara lain menetapkan standar untuk menerima atau menolak resiko tersebut, yaitu dengan menentukan siapa yang berhak menerima kredit yang telah memenuhi standar yang ditetapkan koperasi seperti bagaimana karakter nasabah, kapasitas melunasi kredit, kemampuan modal yang dimiliki nasabah dan jaminan yang dimiliki nasabah untuk menanggung resiko kredit dan kondisi keuangan nasabah.

Berdasarkan latar belakang yang terjadi, bahwa Koperasi Serba Usaha Berkah Tiram Jaya pada proses penyeleksian kriteria dalam menentukan kelayakan anggota untuk menerima kredit masih belum akurat. untuk itu dibutuhkan sebuah metode yang dapat menyeleksi kriteria-kriteria dalam menentukan kelayakan anggota untuk menentukan kredit. Dalam penelitian ini peneliti merancang dan membangun sistem pendukung keputusan pemberian kredit pada Koperasi Serba Usaha BerkahTiram Jaya dengan menggunakan metode AHP(Analytic Hierarchy Process) yang diharapkan dapat 
membantu koperasi Serba Usaha Berkah Tiram Jaya dalam menyeleksi kriteriakriteria untuk menentukan kelayakan anggota menerima kredit.

\subsection{Rumusan Masalah}

bagaimana merancang suatu sistem yang dapat membantu pihak Koperasi Serba Usaha Berkah Tiram Jaya dalam mengambil keputusan untuk menentukan siapa yang layak menerima kredit berdasarkan urutan nilai prioritas tertinggi.

\section{Kajian Literatur}

\subsection{AHP}

Pada dasarnya, proses pengambilan keputusan adalah memilih suatu alternatif. AHP umumnya digunakan dengan tujuan untuk menyusun prioritas dari berbagai alternatif pilihan yang ada dan pilihan-pilihan tersebut bersifat kompleks atau multikriteria.

Penentuan prioritas inilah yang merupakan bagian penting dari penggunaan metode AHP. Pada dasarnya metode AHP merupakan suatu teori umum tentang suatu konsep pengukuran. Metode ini digunakan untuk menemukan suatu skala rasio baik dari perbandingan pasangan yang bersifat diskrit maupun kontinu. Perbandinganperbandingan ini dapat diambil dari ukuran aktual atau dari suatu skala dasar yang mencerminkan kekuatan perasaan dan prefensi relatif.

Peralatan utama AHP adalah sebuah hirarki fungsional dengan input utamanya persepsi manusia akan prioritas antara satu elemen dengan elemen yang lainnya. Keberadaan hirarki memungkinkan dipecahnya masalah kompleks atau tidak terstruktur dalam sub-sub masalah, lalu menyusunnya menjadi suatu bentuk hirarki.

Metode AHP yang dikembangkan oleh Thomas L. Saaty dapat memecahkan masalah kompleks, dimana kriteria yang diambil cukup banyak, struktur masalah yang belum jelas, ketidakpastian persepsi pembuat keputusan serta ketidakpastian tersedianya data statistik yang akurat. Adakalanya timbul masalah keputusan yang sulit untuk diukur secara kuantitatif dan perlu diputuskan secepatnya dan sering disertai dengan variasi yang beragam dan rumit sehingga data tersebut tidak mungkin dapat dicatat secara numerik karena data kualitatif saja yang dapat diukur yaitu berdasarkan pada persepsi, preferensi, pengalaman, dan intuisi

\subsection{Sistem Pendukung Keputusan}

Sistem pendukung keputusan merupakan suatu pendekatan untuk mendukung pengambilan keputusan. Sistem pendukung keputusan, menggunakan CBIS yang fleksibel, interaktif, dan dapat diadaptasi, yang dikembangkan untuk mendukung solusi untuk masalah manajemen spesifik yang tidak terstruktur. Sistem pendukung keputusan menggunakan data, memberikan antarmuka pengguna yang mudah, dan dapat menggabungkan pemikran pengambil keputusan. Sebagai tambahan, sistem pendukung keputusan biasanya mengunakan berbagai model dan dibangun oleh suatu proses interaktif dan iterative. Ia mendukung semua fase pengambilan keputusan dan dapat memasukan suatu komponen pengetahuan.

Karakteristik dan kapabilitas sistem pendukung keputusan dapat dilihat pada gambar 1

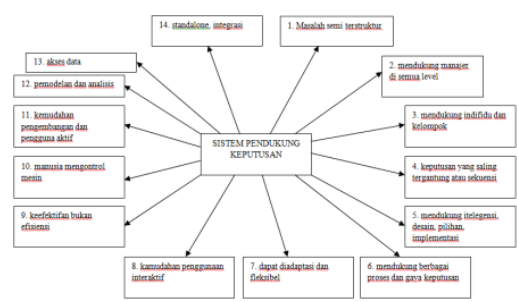

Gambar 1. Karakteristik SPK

\subsection{Koperasi}

Dalam Undang-Undang Perkoperasian Nomor 17 Tahun 2012 Pasal 1 butir (1), yang dimaksud dengan Koperasi adalah badan hukum yang didirikan oleh orang perseorangan atau badan 
hukum Koperasi, dengan pemisahan kekayaan para anggotanya sebagai modal untuk menjalankan usaha, yang memenuhi aspirasi dan kebutuhan bersama di bidang ekonomi, sosial, dan budaya sesuai dengan nilai dan prinsip Koperasi

\subsection{Kredit}

Dalam Undang-Undang Perkoperasian Nomor 17 Tahun 2012 Pasal 1 butir (14), Pinjaman adalah penyediaan uang oleh koperasi simpan pinjam kepada anggota sebagai peminjam berdasarkan perjanjian, yang mewajibkan peminjam untuk melunasi dalam jangka waktu tertentu dan membayar jasa.

Unsur-unsur dalam kredit, sebagai berikut :

1) Adanya dua pihak, yaitu pihak pemberi kredit dan pihak penerima kredit

2) Adanya kepercyaan

3) Adanya persetujuan

4) Adanya penyerahan barang, jasa atau uang dari pemberi kepada penerima

5) Adanya unsur waktu

6) Adanya unsur resiko

7) Adanya unsur bunga sebagai kompensasi

\section{Metode Penelitian}

\subsection{Metode Pengembangan Sistem}

Metode pengembangan sistem yang digunakan oleh penulis yaitu metode pengembangan system berorientasi objek desain dan analisis atau yang disebut dengan OOAD (Object Oriented Analysis and Design).

\subsection{Kerangka Pemecahan Masalah}

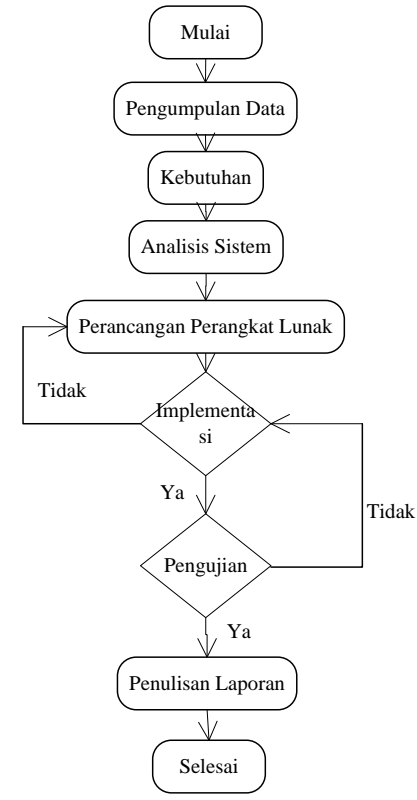

Gambar 2. Kerangka Pemecahan Masalah

\section{Hasil dan Pembahasan}

\subsection{Analisis Sistem Berjalan}

Analisis sistem merupakan kegiatan menguraikan suatu sistem informasi yang utuh dan nyata kedalam komponen yang bertujuan untuk mengidentifikasi serta mengevaluasi masalah-masalah yang muncul, sehingga mengarah pada suatu solusi untuk perbaikan maupun pengembangan kearah yang lebih baik dan sesuai dengan kebutuhan. Berikut adalah prosedur dalam pemberian kredit pada Koperasi Serba Usaha Berkah Tiram Jaya.

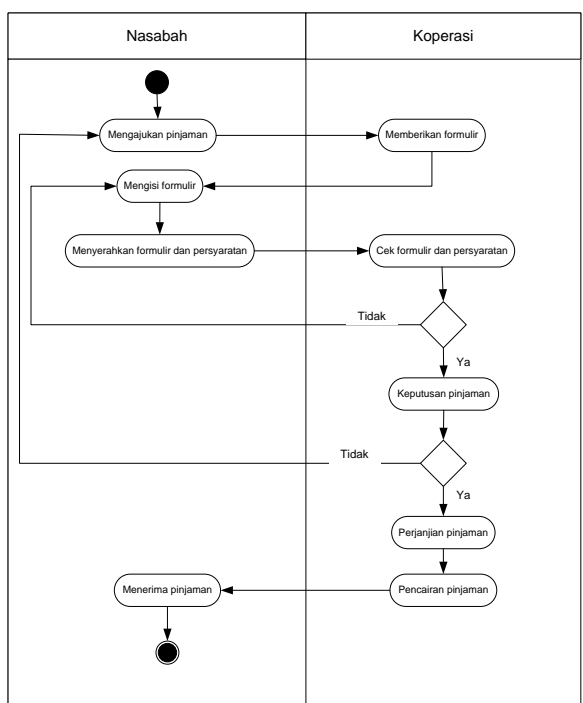

Gambar 3 Diagram Aktivitas Skenario Proses Kelayakan Peminjaman Kredit 


\subsection{Analisis Pemecahan Masalah Menggunakan Metode AHP Struktur hirarki SPK pemberian kredit}

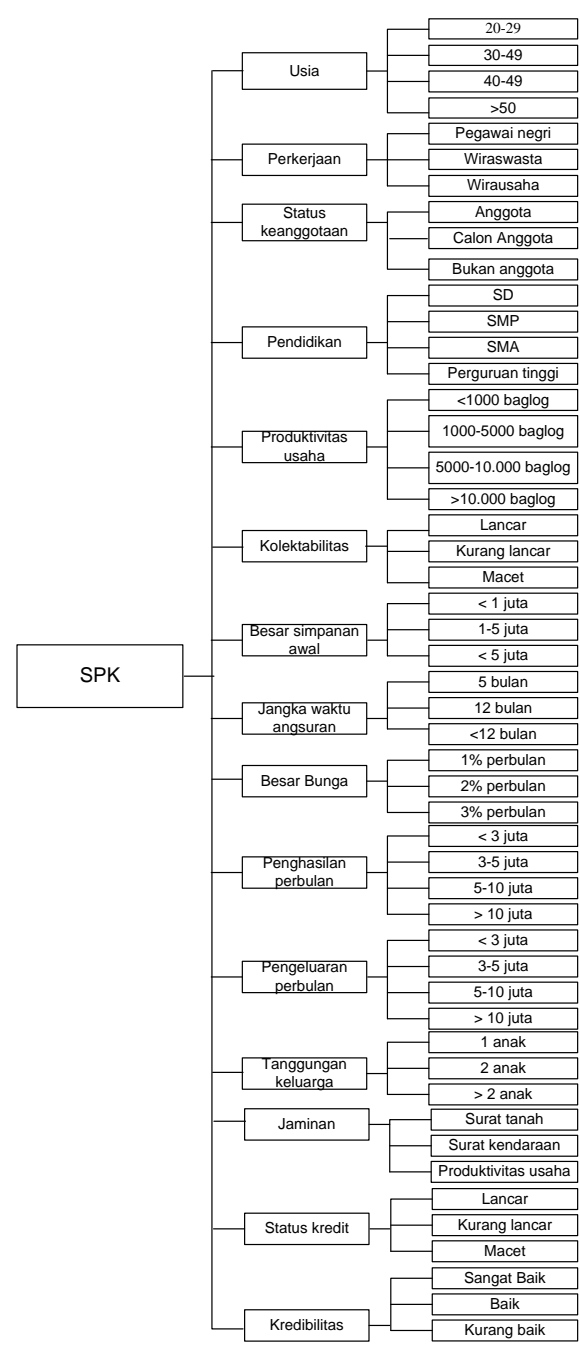

Gambar 4. Struktur hirarki SPK pemberian kredit

1. Nilai matriks kriteria

Menyusun kriteria-kriteria calon nasabah penerima kredit pada matriks berpasangan.

Tabel 1 Nilai matriks perbandingan berpasangan

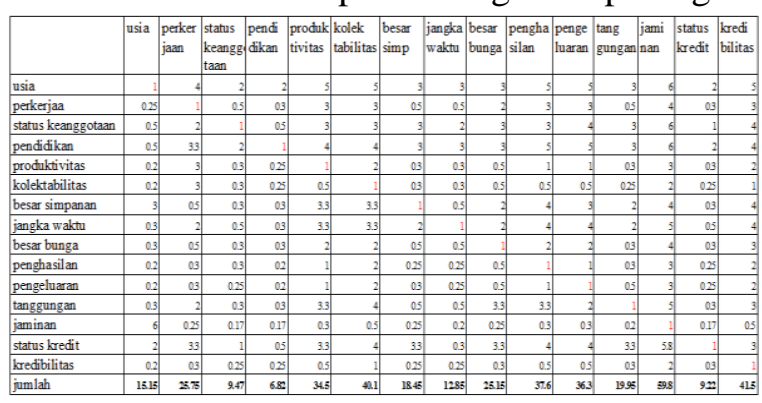

2. Normalisasi
Setelah menyusun nilai matriks kiteria, maka tahap selanjutnya adalah menghitung nilai normalisasi matriks dengan cara membagi nilai masing masing sel dengan jumlah masing masing kolomnya.

Tabel 2. Nilai normalisasi matriks berpasangan

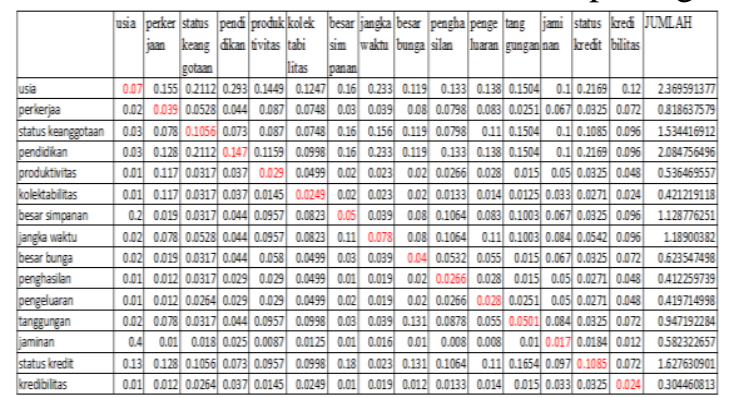

3. Menghitung vektor bobot kriteria

Setelah mendapat nilai normalisasi, kemudian langah selanjutnya adalah menghitung nila vetor bobot kriteri dengan cara membagi jumlah dari setiap baris dengan dengan banyaknya kriteria.

Tabel 3. Nilai vektor bobot kriteria

\begin{tabular}{|l|r|}
\hline \multicolumn{1}{|c|}{ kriteria } & vektor bobot \\
\hline usia & 0.157972758 \\
\hline perkerjaa & 0.054575839 \\
\hline status keanggotaan & 0.102294461 \\
\hline pendidikan & 0.138983766 \\
\hline produktivitas & 0.035764637 \\
\hline kolektabilitas & 0.028081275 \\
\hline besar simpanan & 0.07525175 \\
\hline jangka waktu & 0.079266921 \\
\hline besar bunga & 0.041569833 \\
\hline penghasilan & 0.027483983 \\
\hline pengeluaran & 0.027981 \\
\hline tanggungan & 0.063146152 \\
\hline jaminan & 0.03882151 \\
\hline status kredit & 0.108508727 \\
\hline kredibilitas & 0.020297388 \\
\hline
\end{tabular}

Kriteria usia adalah kriteria paling penting karena memiliki nilai bobot paling tinggi dibandingkan dengan prioritas lainnya.

\section{Memeriksa konsistensi}

Setelah mendapatkan nilai vektor bobot kriteria, kemudian langkah selanjutnya adalah memeriksa konsistensi hirarki dengan cara mengalikan nilai masukan matriks dengan nilai vektor bobot kriteria.

Tabel 4. Nilai konsistensi matriks

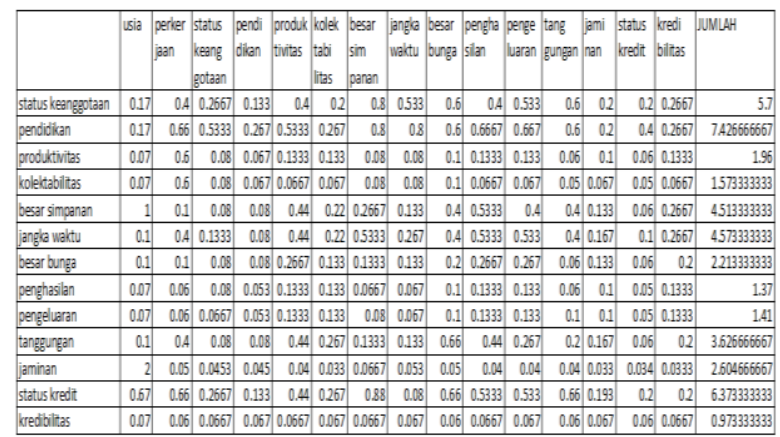

5. Nilai lamda 
Setelah mendapat nilai konsistensi matriks, kemudian langkah selanjutnya adalah mencari nilai lamda maksimal dengan cara membagi jumlah tiap baris nilai konsistensi matruks dengan jumlah kriteria.

Tabel 5. Nilai lamda kriteria

\begin{tabular}{|l|r|}
\hline \multicolumn{1}{|c|}{ Kriteria } & \multicolumn{1}{c|}{ Lamda } \\
\hline usia & 0.551111111 \\
\hline perkerjaa & 0.203777778 \\
\hline status keanggotaan & 0.38 \\
\hline pendidikan & 0.495111111 \\
\hline produktivitas & 0.130666667 \\
\hline kolektabilitas & 0.104888889 \\
\hline besar simpanan & 0.300888889 \\
\hline jangka waktu & 0.304888889 \\
\hline besar bunga & 0.147555556 \\
\hline penghasilan & 0.091333333 \\
\hline pengeluaran & 0.094 \\
\hline tanggungan & 0.241777778 \\
\hline jaminan & 0.173644444 \\
\hline status kredit & 0.424888889 \\
\hline kredibilitas & 0.064888889 \\
\hline jumlah & $\mathbf{3 . 7 0 9 4 2 2 2 2 2}$ \\
\hline lamda max & $\mathbf{0 . 2 4 7 2 9 4 8 1 5}$ \\
\hline
\end{tabular}

Nilai CI $=($ Lamda $\max -\mathrm{n}) /(\mathrm{n}-1)$

$$
\begin{aligned}
& =(0,247294815-15) /(15-1) \\
& =-14,75270519 / 14 \\
& =-1,053764656
\end{aligned}
$$

$$
\begin{aligned}
\text { Nilai CR } & =\mathrm{CI} / \mathrm{RI} \\
& =-1,053764656 / 1,59 \\
& =-0,662745067(\mathrm{CR}<0,1, \text { nilai }
\end{aligned}
$$

Acceptable )

\subsubsection{Rancangan UML (Unified Modelling Language)}

Algoritma $u m l$ pada bab ini merupakan algoritma uml yang akan menjelaskan alur program yang akan dibangun untuk sesuai dengan kebutuhan. Dalam sistem pendukung keputusan ini, penulis menjelaskan dengan beberapa bentuk algoritma uml antara lain adalah menggunakan usecase diagram, aktiviti diagram, diagram urutan dan class dagram.

\subsubsection{Rancangan Usecase}

Usecase diagram dapat menjelaskan beberapa proses yang dapat dilakukan oleh pengelola (admin) dan pengguna (user). Seorang admin dapat melihat informasi, menampilkan informasi, menghapus informasi, mengedit informasi, mengupdate informasi baik itu terkait penentuan prioritas kredit dan faktor- faktor pendukungnya. Sedangkan Seorang pengguna dapat melakukan uji prioritas setiap nasabah.

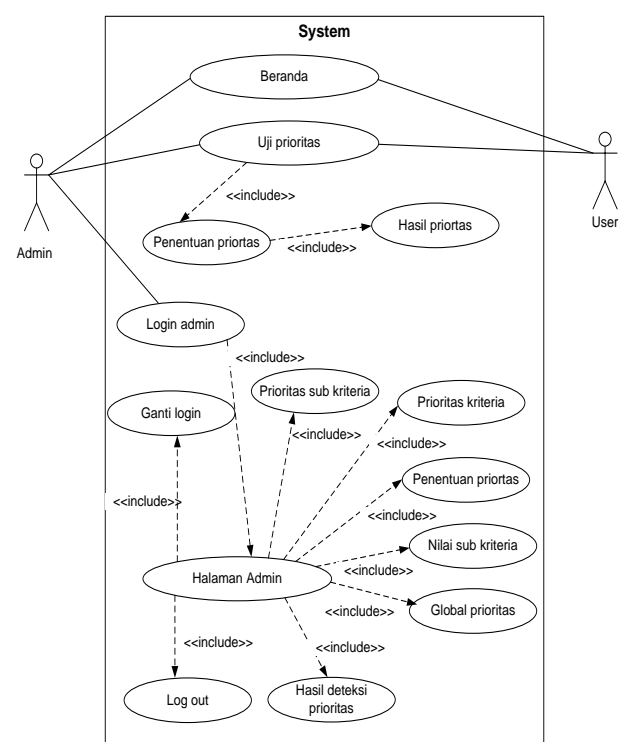

Gambar 5. Rancangan use case SPK pemberian kredit

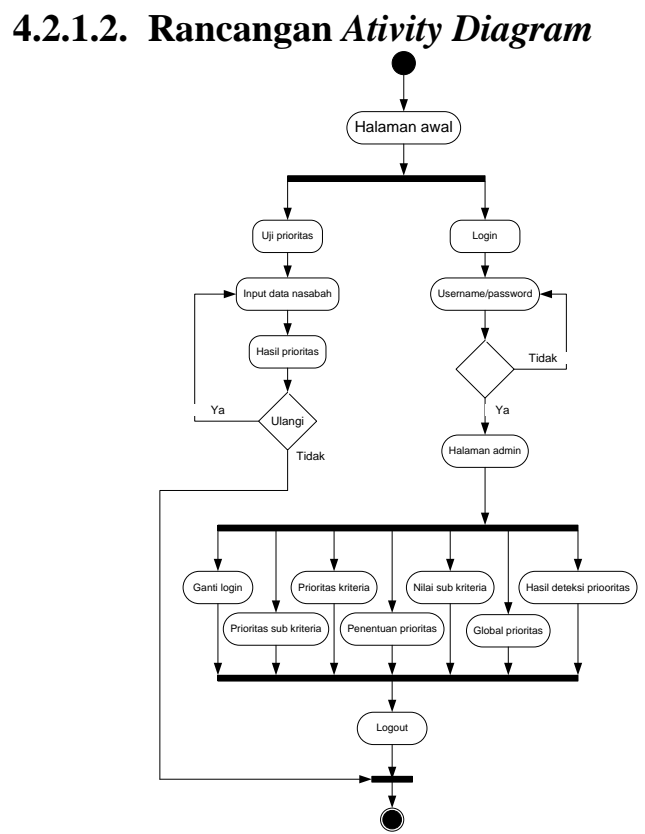

Gambar 6. Rancangan Activity diagram SPK pemberian kredit

\subsubsection{Rancangan Sequence Diagram}

Sequence diagram menggambarkan interaksi antar objek di dalam dan di sekitar sistem (termasuk pengguna, display, dan sebagainya) berupa pesan yang digambarkan terhadap waktu. Sequence diagram terdiri atar dimensi vertikal (waktu) dan dimensi horizontal (objek-objek yang terkait). 


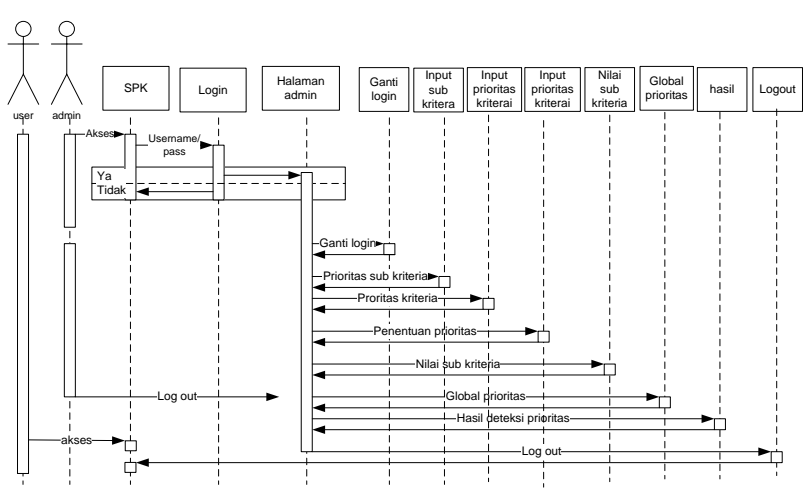

Gambar 7. Rancangan Squence diagram SPK pemberian kredit

\subsubsection{Rancangan Class Diagram}

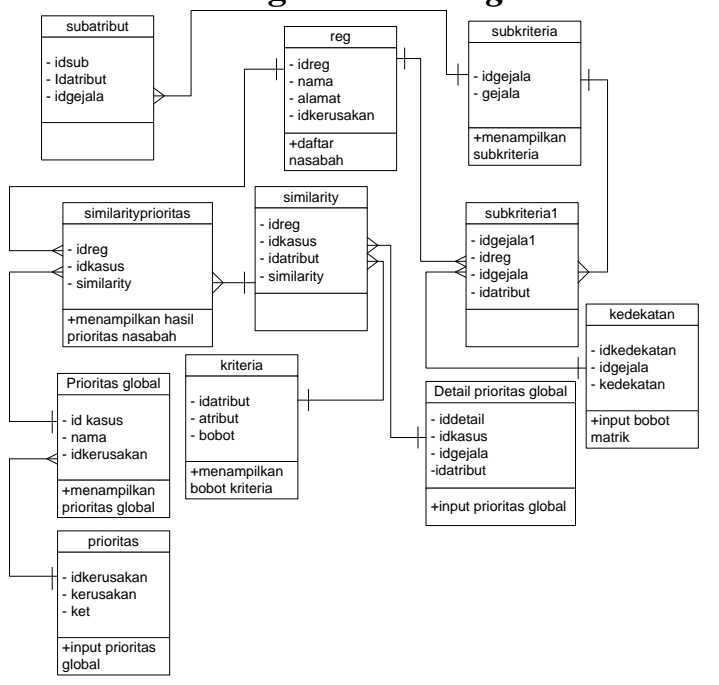

Gambar 8. Rancangan class diagram SPK pemberian kredit

\section{Kesimpulan \\ 5.1 Kesimpulan}

Dari hasil pengujian sistem yang telah dilakukan, maka dapat diambil beberapakesimpulan daiantaranya sebagai berikut:

1. Dalam proses pemberian keputusan, sering kali seksi kredit tidak memberikan keputusan sebagai mana mestinya, dimana nasabah yang memiliki faktor kekeluargaan dengan seksi kredit akan mendapatkan prioritas tertinggi tanpa mementingkan bobot dari masing-masing nasabah lainya.

2. Sistem Pendukung keputusan Pemberian Kredit pada Koperasi Serba Usaha Berkah Tiram Jaya ini dapat membantu pihak Koperasi dalam menentukan nasabah penerima kredit dengan mengambil nilai hasil akhir nasabah dengan prioritas tertinggi.
3. Tampilan aplikasi dalam bentuk grafis dan user friendly dapat membuat pengguna lebih mudah dan nyaman dalam menggunakan aplikasi ini.

Sistem ini hanya menjadi alat bantu bagi pengambil keputusan, keputusan akhir tetap berada di tangan pengambil keputusan

\subsection{Saran}

Berdasarkan hasil penelitian, ada beberapa saran yang sebaiknya dilakukan guna pengembangan sistem ini menjadi lebih baik, diantaranya sebagai berikut:

1. Penggabungan metode Analytical Hierarachy Process (AHP) dengan metode matematika lain dapat membuat niai-nilai pendukung keputusan yang dihasilkan lebih akurat dan terperinci.

2. Dalam aplikasi ini, perlu ditambahkan sebuah halaman yang dapat digunakan untuk menghitung bobot kriteria sehingga tidak memerlukan bantuan sebuah tool untuk mendapatkan nilai bobot setiap kriteria.

3. Pembuatan laporan dalam bentuk print out dapat memudahkan seksi kredit dalam melihat nilai prioritas masing-masing penerima Kredit.

\section{Referensi}

Efraim Tuban, Jay Aronson, Ting P L, 2005, Dicision Support System and Intelligent System, Andi.yogyakarta

Nurdiyanto, H., \& Meilia, H. (2016). SISTEM PENDUKUNG KEPUTUSAN PENENTUAN PRIORITAS PENGEMBANGAN INDUSTRI KECIL DAN MENENGAH DI LAMPUNG TENGAH MENGGUNAKAN ANALITICAL HIERARCHY PROCESS (AHP). SEMNASTEKNOMEDIA ONLINE, 4(1), 3-3.

Nurdiyanto, H., \& Hermanto, H. (2016). Signature Recognition Using Neural Network Probabilistic. International Journal of Advances in Intelligent Informatics, 2(1).

Pressman S R, 2010. Rekayasa Perangkat Luna (Buku 1), Andi. Yogyakarta. 